\title{
Supply chain management enablers, barriers and disruptions in the animal feed industry in the Western Cape Province of South Africa
}

\begin{tabular}{|c|c|}
\hline $\begin{array}{l}\text { Authors: } \\
\text { Pauline Mada } \\
\text { Gomera }{ }^{1} \\
\text { Chengedzai M }\end{array}$ & mombe \\
\hline $\begin{array}{l}\text { Affiliation: } \\
{ }^{1} \text { Graduate Sch } \\
\text { Leadership, U } \\
\text { South Africa, } \\
\text { South Africa }\end{array}$ & $\begin{array}{l}\text { 1ool of Business } \\
\text { niversity of } \\
\text { Johannesburg, }\end{array}$ \\
\hline $\begin{array}{l}{ }^{2} \text { Department } \\
\text { Faculty of Ma } \\
\text { Sciences, Vaal } \\
\text { Technology, V } \\
\text { South Africa }\end{array}$ & $\begin{array}{l}\text { of Logistics, } \\
\text { nagement } \\
\text { University of } \\
\text { anderbijlpark, }\end{array}$ \\
\hline $\begin{array}{l}\text { Correspondin } \\
\text { Chengedzai M } \\
\text { chengedzai@ }\end{array}$ & $\begin{array}{l}\text { g author: } \\
\text { lafini, } \\
\text { hotmail.com }\end{array}$ \\
\hline $\begin{array}{l}\text { Dates: } \\
\text { Received: } 14 \\
\text { Accepted: } 13 \\
\text { Published: } 29\end{array}$ & $\begin{array}{l}\text { Apr. } 2020 \\
\text { May } 2020 \\
\text { June } 2020\end{array}$ \\
\hline $\begin{array}{l}\text { How to cite th } \\
\text { Gomera, P.M. } \\
\text { 2020, 'Supply } \\
\text { management } \\
\text { barriers and d } \\
\text { the animal fee } \\
\text { the Western C } \\
\text { South Africa', } \\
\text { Transport and } \\
\text { Management } \\
\text { https://doi.or } \\
\text { jtscm.v14i0.5 }\end{array}$ & $\begin{array}{l}\text { his article: } \\
\text { \& Mafini, C., } \\
\text { chain } \\
\text { enablers, } \\
\text { lisruptions in } \\
\text { ed industry in } \\
\text { Cape Province of } \\
\text { Journal of } \\
\text { Supply Chain } \\
14(0) \text {, a510. } \\
\text { g/10.4102/ } \\
10\end{array}$ \\
\hline $\begin{array}{l}\text { Copyright: } \\
\text { (c) 2020. The } \\
\text { Licensee: AOS } \\
\text { is licensed un } \\
\text { Creative Com } \\
\text { Attribution Lic }\end{array}$ & $\begin{array}{l}\text { Authors. } \\
\text { slS. This work } \\
\text { der the } \\
\text { mons } \\
\text { cense. }\end{array}$ \\
\hline Read online: & \\
\hline 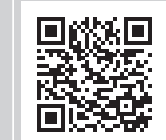 & $\begin{array}{l}\text { Scan this QR } \\
\text { code with your } \\
\text { smart phone or } \\
\text { mobile device } \\
\text { to read online. }\end{array}$ \\
\hline
\end{tabular}

Authors:

Gomera $^{1}$ (1)

Affiliation:

${ }^{1}$ Graduate School of Busines Leadership, University of South Africa, Johannesburg, Faculty of Management Sciences, Vaal University of Technology, Vanderbijlpark, Corresponding author: Chengedzai Mafini, chengedzai@hotmail.com

Dates:

Accepted: 13 May 2020

How to cite this article: Gomera, P.M. \& Mafini, C. 2020 , 'Supply chain management enablers, the animal feed industry in the Western Cape Province of Transport and Supply Cha in https://doi.org/10.4102/ jtscm.v14i0.510

Copyright: Licensee: AOSIS. This work is licensed under the Creative Commons Attribution License.
Background: The animal feed supply chain in South Africa is an important industry that has experienced numerous changes as it evolved. However, not much is known empirically about the dynamics of implementing supply chain management (SCM) in the animal feed industry in specific South African contexts.

Objectives: This study investigates the SCM-related factors for growth (enablers), barriers and disruptions within the animal industry in the Western Cape Province of South Africa.

Method: This study used a qualitative method in which managers drawn from the animal feed industry in the Western Cape Province were interviewed. The collected data were examined using thematic analysis.

Results: This study showed that the use of technology to achieve goals, bargaining power of the industry and unity, and procurement and supply chain strategy served as the main SCM enablers. The lack of infrastructure, ineffective change management, health and safety, nature of the industry, and skills and qualifications are the primary barriers hindering the effective implementation of SCM. Economic factors, natural disasters and diseases, and a lack of customer loyalty within the animal feed industry were the main SCM disruptions highlighted in the study.

Conclusion: This study provides information regarding the factors (enablers) that deserve attention when developing interventions to improve the performance of the animal feed supply chain. The information on SCM barriers and disruptions is relevant when developing risk management initiatives in the animal feed industry.

Keywords: supply chain management; enablers; barriers; disruptions; animal feed; Western Cape province.

\section{Introduction and background}

South Africa has a diversified economy, which is based on various sectors that contribute in different ways to its growth and productivity. One of these sectors is agriculture, which consists of several industries such as crop production, fruit and viticulture, agro-processing, aquaculture (fish farming) and livestock production, amongst others (Bolton 2015). Each of these industries has a unique role and contribution to the agrarian project in South Africa. Within the agriculture sector, livestock production stands out as one of the most common and oldest practices, having transitioned together with humanity from the hunter-gatherer lifestyle to modernised farming (Clutton-Brock 1999; McTavish et al. 2013). In South Africa, livestock production includes the breeding and raising of domesticated animals for consumption (meat), eggs, milk, fur, hides and dung, amongst other products (van Ryssen 2014). The most commonly produced livestock in the country are cattle, pigs, goats, sheep, ostrich and domesticated venison (game such as buffalo, antelope, springbok and so on) (Department of Agriculture, Forestry and Fisheries [DAFF] 2020). Value-added services such as fattening, slaughtering, processing and preservation of meat, as well as draught power and the crossbreeding of livestock, are also offered. The livestock production industry accounts for at least $40 \%$ of the total value of agriculture whilst its earnings amount to an estimated $10 \%$ of agricultural exports in South Africa, making it an important economic player in the country (Digital Agriculture and Farming Handbook 2020).

An upstream niche that is an essential feeder to the livestock supply chain is the animal feed industry, which produces the food for animals. In South Africa, the animal feed industry has direct and indirect influences and importance to the South Africa economy. For instance, it 
indirectly boosts the South Africa economy through the provision of grain and oilseed. Most raw materials for animal feed are produced from grains and oilseed by-products such as sunflower, soya, rapeseed and peanuts are a critical source of protein for animals (The Organic Farmer 2020). The local grains and oilseed cluster is one of the largest agricultural sectors, which is a significant subscriber to the country's gross domestic product (GDP) (Jahari et al. 2018).

Notwithstanding the importance of the animal feed industry to the South African economy, some unique challenges exist that provide an impetus for continued research in this context. A topical challenge is the importation of raw materials required in the production of animal feed. Local protein availability has emerged as a key problem, as a result of the high demand for commodities such as soybean, leading to an increasing scarcity of protein for animal feed (Louw, Schoeman \& Geyser 2013). This scarcity has pressured animal feed manufacturers to procure this valuable protein from international sources. The procurement of these raw materials from global suppliers brings with it several headaches, with the volatility of the South African rand being a leading hindrance. For instance, over the past decade, the value of the South African rand has weakened by over $60 \%$ against the greenback (USD), which is the standard currency globally (South African Reserve Bank 2020). The weakening of the domestic currency has made the importation of raw materials expensive for local animal feed producers. With such costly inputs, it has become necessary to manage the local animal feed supply chain judiciously to maintain its cost-effectiveness and to keep retail prices of the final products affordable to livestock producers. High prices themselves are unsustainable because the propensity to switch to cheaper imports and other substitute animal feed products is high amongst local livestock producers in South Africa (Agriculture News South Africa 2018).

Another problem facing the animal feed industry relates to the observance of regulations regarding the use of genetically modified products. Regulations regarding such products are set by the Animal Feed Manufacturers Association (AFMA) and affect competitiveness in the industry as some livestock farmers and consumers prefer an organic feed. Sporadic outbreaks of animal epidemics such as avian influenza (AI) in 2016 and foot and mouth disease between 2018 and 2019 have also left significant scars on the feed industry (Agriculture News South Africa 2018; Evans 2019; Watson 2019). Moreover, its dependence on the agricultural sector for raw materials such as maize and oilseed has made the animal feed industry susceptible to the frequent spells of low rainfall experienced in South Africa in the last decade (Department of Environmental Affairs 2017; Rust \& Rust 2012). More recently, the outbreak of the novel coronavirus (COVID-19) pandemic in early 2020, which led to the freezing of most economic activities worldwide and the downgrading of South Africa to 'junk status' by the major rating agencies, also disrupted productivity in most sectors (Stone \& Masondo
2020; van der Merwe et al. 2020). The animal feed industry was not spared by these adverse developments.

In light of the developments above, this study investigates the supply chain management (SCM)-related factors for growth (enablers), barriers and disruptions within the animal feed industry in the Western Cape Province. Enablers are factors that stimulate the ability to attain sustainable supply chains, and examples include infrastructure, technology, strategic alliances and human resource management, amongst others (Lysons \& Farrington 2012). Barriers are the forces that work against supply chain processes, such as the lack of skills, systems, practices and relationships (Kim, Chen \& Linderman 2015). According to the Chartered Institute of Procurement and Supply (CIPS 2016), supply chain disruptions are unplanned and unanticipated events that interrupt the normal flow of goods and materials in a supply network. The leading supply chain disruptions include fires and explosions, natural disasters together with harsh weather conditions, machinery breakdowns, faulty designs of materials during manufacturing, strikes, riots and vandalism, human error, power and water interruptions (CIPS 2016). Despite the challenges faced in the animal feed industry, the specific SCM enablers and disruptions relevant to it within the Western Cape are yet to be specified empirically. This study is intended to produce information that can be used to ensure that the animal feed industry in that province is conducive to managing and eradicating current problems. Hence, information on the SCM enablers, barriers and disruptions may be harnessed and channelled to ensuring that the animal feed supply chain in the Western Cape is successful.

Several studies have been conducted which focused on the South African animal feed industry. Examples include researches by Dunn (2017), Meissner, Scholtz and Palmer (2013) and Maré (2017). However, evidence of studies that investigated SCM enablers and disruptions in the animal feed industry in South Africa is rare. To a large extent, most studies in South Africa have directed emphases to the general agricultural sector, which in turn has a direct impact through raw materials to the animal feed. This points to a gap in the literature in industry-specific SCM in South Africa, further making it necessary to conduct this study.

\section{Literature}

The literature review focuses on the animal feed industry and supply chain in South Africa.

\section{The animal feed industry in South Africa}

Animal feed industries facilitate the manufacturing of food that provides proteins to animals worldwide. According to Gonera (2018), animal feed is amongst the most significant and critical components in ensuring safe, abundant and affordable animal proteins. In South Africa, the animal feed industry began to grow in the 1930s, actuated by difficulties stemming from the great depression and a series of droughts during these formative years (DAFF 2018). Its steady growth 
culminated in the introduction of scientific methods of producing animal feed (DAFF 2018). By 2017, South Africa was the highest animal feed producer on the African continent and ranked number 22 worldwide (Animal Feed Manufacturers' Association [AFMA] 2019). The industry contributes an estimated 3.5 million tonnes (MT) of animal feed to the South African livestock market and more than $11 \mathrm{MT}$ to the world market per annum (AFMA 2018). Globally, poultry feed accounts for the most substantial share in the overall feed consumption followed by ruminants, pig, aquaculture and other species (Department of Agriculture, Forestry and Fisheries [DAFF] 2018; Ncube et al. 2017).

The primary animal feed ingredient in South Africa is maize, with an inclusion rate estimated at $52 \%$, followed by soya bean meal at $14 \%$, sunflower seed at $4 \%$ and fishmeal at $0.2 \%$ (AFMA 2018). In terms of usage projects, an estimated 2.5\% increase in the consumption of animal feed supply chain in South Africa was predicted between 2017 and 2022, and the level of protein used within the same industry was also expected to rise by an average $4.6 \%$ every year in that period (BizVibe 2018). However, a report compiled by AFMA (2018) indicates that sales within this industry have been falling steadily between the highest negative growth of $6.2 \%$ in 2017 and a minimum of $0.3 \%$ in 2019 for most categories of animal feed. In South Africa, particularly in the Western Cape, the feed industry is made up of businesses that have managed to acquire modernised computerised plants, latest equipment for analytical procedures and use state-of-the-art technology to ensure that quality feed is produced (Gonera 2018).

\section{The animal feed supply chain}

In attempting to design useful business models, companies have adopted SCM as a business strategy. Supply chain management includes all activities associated with the flow of products and services, from raw materials to finished products (Lysons \& Farrington 2012). Specifically, SCM is defined as the design and management of seamless, valueadded processes across organisational boundaries to meet the real needs of the end customer (Fawcett, Ellram \& Ogden 2014). The supply chain of a particular product ranges from raw material suppliers, through manufacturing and distribution, to retailers who sell the final product to consumers (Lysons \& Farrington 2012). A supply chain is thus defined as a network of organisations involved in making end products available to customers. It includes all functions, processes and activities involved in sourcing, creating and delivering products or services to customers (Du Toit \& Vlok 2014).

Supply chain management plays a strategic role in the animal feed industry as its various practices are used to facilitate a seamless supply of the product to customers. Suppliers of raw materials are a shared pool which is utilised by the entire industry. Prices of raw materials are determined by market forces, and the procurement of various raw materials from preferred suppliers before production begins at the mills is anchored on demand planning (Ncube, Roberts \& Zengeni 2016). Most of the producers of animal feed have storage facilities in their premises to ensure sufficient lead times. A majority of manufacturers produce the animal feed on demand instead of keeping ready-made stock for long periods. The low-stock option is premised on the limited shelf-life of animal feed, as the product is made of ingredients that deteriorate over time (Le Bars \& Le Bars 1998). Moreover, when producing animal feed, it is often necessary to include some customised additives such as specific dietary and veterinary supplements that guarantee an accelerated growth rate, protection of health from pathogenic infections and improvement of other production parameters such as absorption of feed and quality of meat, milk and eggs (Markowiak \& Śliżewska 2018). This is a risk management measure as the bulk of the animal feed produced is supplied directly to the farms and the rest (which is a minimum) is then marketed through retailers. This guarantees continuous production at all times. Through dedicated sales and marketing teams, orders for animal feed are obtained directly at the mills from farmers, wholesalers or retailers, which leads to a more aligned production process. Distribution of the animal feed to respective customers is then performed once the invoicing process has been completed (Gonera 2018).

\section{Research methodology}

The research methodology covers the research approach and design, sampling, data collection, data analysis and trustworthiness.

\section{Research approach and design}

In this study, a phenomenological paradigm was followed as the study was directed at understanding the perceptions of specific individuals concerning the SCM situation in the animal feed industry. A phenomenology-based qualitative research approach was used to conduct this study. Qualitative research is about recording, analysing and attempting to uncover the more profound meaning and significance of human behaviour and experience, including contradictory beliefs, practices and emotions (Blumberg, Cooper \& Schindler 2014). Use of the qualitative approach in this study allowed participants the freedom of expression and provided them with leeway to respond honestly. The qualitative approach is less rigid and allows for thoughts, feelings and behaviour to be used rather than when they select from predetermined responses (Leedy \& Ormrod 2015).

\section{Sampling design}

The target population for this study were managers drawn from the animal feed industry in the Western Cape Province. The sampling frame for this study is a list maintained by the AFMA. The record shows all firms within the animal feed industry that are full members of the association and have gone through the AFMA audit according to its code of conduct. 
A non-probability purposive sampling approach was used to select participants. Non-probability sampling occurs when there is no way of either predicting or guaranteeing that each element of the target population will be represented in the sample (Leedy \& Ormrod 2015). In purposive sampling, people or units are chosen for a particular purpose (Cresswell \& Plano Clark 2011). In this research, only managers who had worked for at least 2 years in the animal feed industry were recruited as participants. There was no pre-set sample size for participants because the study used the sequential method of data collection in which the saturation point determined the sample size.

\section{Data collection}

Data were collected through the use of face-to-face semistructured in-depth interviews. A semi-structured in-depth interview is one in which the interviewer has a checklist of topic areas or questions, with the aim of making the participants to talk in their own terms (Jamshed 2014). An interview protocol was developed to aid the process of data collection and was used in interviews that lasted for periods ranging between $20 \mathrm{~min}$ and $30 \mathrm{~min}$ per session. The interviews were conducted at selected premises in Cape Town between August and September 2018. A voice recorder was used to record all conversations.

\section{Data analysis techniques}

The collected data were transcribed from the voice format to word using the services of a professional transcriber. After that, the thematic analysis procedure was used to analyse the data. According to Nowell et al. (2017), thematic analysis is a method for identifying, analysing, organising, describing and reporting themes found within a data set. The six-step thematic analysis procedure recommended by Braun and Clarke (2006) was followed. First, the researchers familiarised themselves with their data. Second, the contexts of the conversations being conducted were generated. The third step was to search and interpret collated codes. The fourth step was to review all themes, and the fifth step was to define and name the themes. The final step involved producing the research report.

Several ethical considerations, such as informed consent, voluntary participation, participant anonymity, confidentiality and protection from victimisation, were followed in this study.

\section{Trustworthiness}

Acceptability of the results of the study was improved by ensuring that the research process and the findings were trustworthy. Four measures of trustworthiness that were employed are credibility, transferability, confirmability and dependability. Credibility establishes whether the research findings represent plausible information drawn from the participants' original data and is a correct interpretation of the participants' original views (Korstjens \& Moser 2018).
Credibility was achieved using a purposive sample, which ensured that only those individuals whose knowledge and experience in the animal feed industry were selected as participants, thereby producing insights relevant to the study. Transferability refers to the degree to which the findings can apply to other contexts, circumstances and situations (Lee \& Lings 2008). Transferability was ascertained through making constant reference to similar scenarios and cases within the animal feed industry in other provinces of South Africa. In this study, it was recognised that the animal feed industry in the Western Cape is similar to those in other provinces in South Africa, given that the industries are in the same country and they all face similar political, economic, social, technological, legal and ecological (PESTLE) dynamics. In this sense, the animal industry in South Africa was considered to be homogenous, and hence, the findings from this study could be extrapolated to other provinces.

Confirmability of the conclusions was ascertained through an audit trail, ensuring that participants were allowed to provide their input into the word transcripts of their interviews so that they could indicate wherever they felt that corrections were necessary. Nine participants out of the original 12 were available to confirm that the transcripts were a correct representation of the proceedings of the interviews. The transcripts for the other three participants were, therefore, not included in the final analysis. This procedure helped to establish that the research findings were able to portray participants' responses accurately. Lastly, dependability is the stability of the research findings over time (Lincoln \& Guba 1985). Dependability of the findings was ensured by triangulating the data collection process, which is the collection of data from different sources to ensure that the insights gained are all-inclusive. In this study, triangulation was implemented through the collection of data from demographically diverse individuals in areas such as levels of experience, education, age and their official positions in the animal feed industry. Confirmability is the degree of neutrality in the findings of a study. In other words, it suggests that the findings are based on participants' responses rather than any potential bias or personal motivations of the researcher (Corbin \& Strauss 2008).

\section{Research findings}

The research findings include a description of the findings, implementation of SCM in the animal feed industry, SCM practices that have received primary attention in the animal feed industry, themes emerging from the study, conclusions, theoretical and managerial implications, and limitations and suggestions for future research.

\section{Description of the sample}

A total of 12 managers drawn from the animal feed industry were interviewed. However, three managers responded late and hence were considered to be unavailable to confirm the accuracy of their transcripts in the audit trail. As a result, 
their insights were excluded from this study, leaving nine participants whose ideas were captured and used in the final analysis of data. An extensive body of book chapters, scholarly articles and books (e.g. Baker \& Edwards 2012; Charmaz 1990; Dworkin 2012; Morse 2000) recommend guidance and suggest anywhere from five to 50 participants as adequate for qualitative interviews. Moreover, in this study, saturation, which is the point at which the data collection process no longer offers any new or relevant data (Mason 2010), was reached at eight interviews, although 12 interviews were conducted eventually. The final sample size of nine participants was therefore recognised as sufficient for this study. The demographic profiles of all participants are presented in Table 1.

Table 1 shows that the final participants included nine managers representing all levels of management. Six were male participants, and all participants had more than 5 years of experience within the animal feed supply chain.

\section{Implementation of supply chain management in the animal feed industry}

There were mixed views regarding the implementation of SCM in the animal feed industry. Some of the participants indicated that there was a lack of implementation and enforcement of SCM in the industry. This is captured by the following quotations from some of the participants:

'SCM has not been implemented well. Looking at the past the mode of transport used was rail, and everything was centred on that. The set up was unstructured. That has been carried over the past years, yet it is time to move on and look at what works now. There is now a lot of basis on raw materials being delivered and a lot more control of the products but how things are done is outdated.' (P2, Male, Procurement Manager, Age 45-50 years)

'SCM has been implemented to about 50\% based on personal opinion. There is no clear communication line between departments as products come from primary suppliers to endusers. There are vacuums in operations, and thus roles are not clearly shown, and this leaves everyone not sure who is responsible for what.' (P8, Female, Procurement Manager, Age 40-50 years)

On the contrary, some participants acknowledged that SCM had been implemented fractionally in their firms. This is illustrated in the following extracts from the finance and logistics managers, respectively:

\begin{tabular}{lllll}
\multicolumn{2}{l}{ TABLE 1: Demographic profile of participants. } \\
\hline Participant code & Gender & $\begin{array}{l}\text { Age Group } \\
\text { (years) }\end{array}$ & Position occupied & $\begin{array}{l}\text { Years of } \\
\text { experience in } \\
\text { the industry }\end{array}$ \\
\hline P1 & M & $25-30$ & Demand Planning Manager & 5 \\
P2 & M & $45-50$ & Procurement Manager & 15 plus \\
P3 & M & $30-40$ & Finance Manager & 10 \\
P4 & M & $60-65$ & Transport Director & 30 plus \\
P5 & M & $50-60$ & Supply Chain Executive & 20 plus \\
P6 & F & $30-40$ & Purchasing Manager & 20 \\
P7 & F & $40-50$ & Finance Manager & 15 \\
P8 & F & $40-50$ & Procurement Manager & 20 \\
P9 & M & $30-40$ & Logistics Manager & 12 \\
\hline
\end{tabular}

F, female; $M$, male.
'SCM has been implemented extensively in that we have a centralised procurement department responsible for the procurement of raw materials from suppliers right to delivery at the plants, operations of the plants, effective centralised procurement for operating expenses, up to the management of the delivery of the final product to the customer.' (P7, Female, Finance Manager, Age 40-50 years)

'From my perspective, SCM has been implemented to a point where internal controls have been taken into consideration. This has been done through ensuring that the mitigation of risks is in place. The organisation has implemented systems with steps that involve middle management, and senior management is in place regarding approval before procurement. There are a lot of internal controls in place as the supply chain plays a major role.' (P9, Male, Logistics Manager, Age 30-40 years)

From the participant's various perspectives, SCM is present in the industry, but more considerable effort is required to ensure that all stakeholders understand its importance and implementation. As the flow of SCM strategy is top-down, its application is ineffective when any level is either excluded or unaware of its role. According to Sridharan, Caines and Patterson (2005), the main reason for the implementation of SCM practices is to add value and improve operations, which, if not correctly performed, can lead to the disruptions of firm operations. Such disturbances can have substantial negative consequences on the firm, which will, in turn, affect its performance. Thus, the divergent views on the level of implementation suggest the importance of ensuring that SCM training and education are both discussed and prioritised in the animal feed industry, to avert the possible detrimental effects associated with poor execution.

\section{Supply chain management practices that have received primary attention in the animal feed industry}

Supply chain management practices are applied either internally or externally to each firm in the network. Different views were received from the participants regarding the SCM practices their firms were implementing. Below are excerpts from participants regarding the SCM practices prioritised in their firms:

'Transportation of raw materials has primary attention, yet logistics should be the core of the supply chain.' (P4, Male, Transport Director, Age 60-65 years)

'The procurement of raw materials for producing animal feed.' (P6, Female, Purchasing Manager, Age 30-40 years)

'There is a movement of too many products to be procured, and for this, there are few people doing that job. There is few and at times no people responsible for stock control.' (P1, Male, Demand Planning Manager, Age 25-30 years)

The responses above indicate that the transportation of raw materials and procurement seems to be the primary supply chain management practices in the animal feed industry. This situation is to be expected, given that the animal feed industry involves the movement of bulk materials (for making feed, plus the outputs) from suppliers and to customers 
(farmers and retailers). The processes are driven by procurement as it initiates the process of acquiring the raw materials. Prioritising these functions should optimise the costs related to the acquisition and distribution of both the raw materials and animal feed. However, other SCM practices such as storage, supplier and customer services management remain essential and should be prioritised.

\section{Themes emerging from this study}

The themes that emerged from the study are categorised into three categories:

- Enablers of SCM are factors that promote the success of supply chains.

- Barriers to SCM are the forces that work against supply chain processes.

- Disruptions of SCM are unplanned and unanticipated events that upset the normal flow of goods and materials in supply chains.

\section{Enablers of supply chain management}

Thematic analysis of the collected data led to the extraction of three subthemes, namely technology, bargaining power of industry and procurement and supply chain strategy. These subthemes are the SCM enablers in the animal feed industry. The operational definitions of these subthemes are provided in Table 2.

\section{Technology}

Participants noted the importance of technology in driving SCM in the animal feed industry. They seemed to appreciate the benefits of using technology in their firms. The transport director recognised how technology is playing a decisive role and impacting SCM in his firm, as indicated in the following excerpt:

'Upgrading and use of high-end technology have had a huge impact on the feed supply chain. The use of satellite tracking, WhatsApp, dashboard cameras have made communication and planning so much easier.' (P4, Male, Transport Director, Age 6065 years)

The finance manager further reiterated the positive impact of the use of technology in her firm. This is indicated in the following remark:

'Although we faced challenges in implementing new technology, there has been a huge difference from when we only relied on email and phone calls. The new Enterprise Resource Planning systems are also useful in pulling all data through in one place

TABLE 2: Operational definitions for supply chain enablers.

\begin{tabular}{lll}
\hline No. & Subtheme & Operational definition \\
\hline I & Technology & $\begin{array}{l}\text { This refers to the use of technology to achieve the } \\
\text { desired goals. }\end{array}$ \\
II & $\begin{array}{l}\text { Bargaining power of This refers to the pressure directed by the industry to } \\
\text { industry and unity }\end{array}$ & $\begin{array}{l}\text { suppliers as they work as a collective. } \\
\text { III } \quad\end{array}$ \\
$\begin{array}{l}\text { Top management } \\
\text { commitment }\end{array}$ & $\begin{array}{l}\text { This refers to how top management is committed to } \\
\text { ensuring that the entire supply chain works as a } \\
\text { collective whilst aiding the firm's strategy. }\end{array}$ \\
\hline
\end{tabular}

when needed, especially running month-end and year-end inventory figures.' (P7, Female, Finance Manager, Age 40-50 years)

It is notable that where technology has been adopted, significant paybacks have been realised and participants recognise them. As mentioned by Auramo, Kauremaa and Tanskanen (2005), most firms derive their success from focusing on how technology can improve their strategy and operations, as the adoption of recent technologies can improve efficiency, information sharing and quality, which is vital for competitive advantage. Thus, the animal feed industry can realise such benefits through the adoption and implementation of recent and disruptive technologies.

\section{Bargaining power and unity of the industry}

Within the animal feed industry, AFMA, which is the regulatory body, plays a critical role in ensuring that collaboration and unity exist in the entire supply chain. Through the rules and regulations set by the association, as well as its efforts in holding symposiums, workshops and meetings, most players in the animal feed supply chain have managed to operate collectively and to complement each other's efforts. This view is reflected by the quotations from the supply chain executive, procurement manager and finance manager, respectively:

'Efficiency in imports and storage showed a fair amount of maturity in the industry. This was also boosted when all suppliers worked together to ensure supply was not interrupted in the importation of raw materials and products in the industry.' (P5, Male, Supply Chain Executive, Age 50-60 years)

'When there was the biosecurity issue in the industry, even transporters worked together to ensure no cross-contamination. Everyone teamed up to ensure no spreading of the Avian influenza and also prices were not increased drastically to benefit one supplier or producer cashing in on the problem. AFMA played a huge role in ensuring all players stuck together. Interaction and affiliations with AFMA where we share ideas and problem solving as a collective.' (P6, female, Procurement Manager, age $30-40$ years)

'The negotiating of more competitive national prices, and the procurement on a large scale, has given a more effective bargaining tool for prices.' (P7, female, Finance Manager, age 40-50 years)

The responses by participants demonstrate the importance of the role of communities of practice, such as AFMA in creating and nurturing collectiveness within the animal feed industry. Players in the supply chain realise the importance of unity and partnering and have started competing as a supply chain rather than as individual entities. As mentioned by one of the participants, supply chain partners formed synergies to fight the outbreak of AI because they understood the possible impact of a spread of this disease to the entire industry. Hence, there appear to be stronger bonds between the supply chain partners in the animal feed industry, providing them with higher bargaining power to influence each other positively. 


\section{Top management commitment}

Executive commitment to achieving SCM goals was acknowledged as one of the primary reasons for the successes achieved in the animal feed industry. The comments below are from the procurement and transport managers who shared their sentiments regarding the implementation of a supply chain strategy:

'The decision by the strategic team to play any role in the procurement of raw materials has led to the implementation of a centralised procurement store. The operations of this store have been given over to the procurement team, and the responsibility lies with them. In the long run, this has led to specialisation by staff in strategic sourcing which has resulted in the more effective management of the organisation.' (P2, male, Procurement Manager, age $45-50$ years)

'There has been huge support from the head office in getting on board experienced personnel who have strong leadership. The succession plan has ensured that there is a blend of young and old staff bringing fresh ideas on the table. There is the development of staff which enhances innovative ideas.' (P4, male, Transport Director, age 60-65 years)

As shown above, participants applauded the role the executive management is playing in ensuring a continuous and efficient SCM process in the animal feed industry. Some of the areas where the commitment of executive management has produced results include procurement, staff development and innovation. Thus, support from top management in the animal feed industry has proved to be critical in facilitating the success of the industry.

\section{Barriers of supply chain management}

Five subthemes, namely infrastructure, change management, health and safety and the nature of the industry were identified as the barriers to the implementation of SCM in the animal feed industry. The operational definitions of these subthemes are presented in Table 3.

\section{Infrastructure}

The lack of adequate infrastructure emerged as a topical barrier obstructing the flow of goods in the animal feed industry. There are unfavourable conditions within the industry that slow down the supply chain daily. The remarks from the transport director and the logistic manager underscore the extent to which infrastructure has negatively impacted the supply chain:

TABLE 3: Operational definitions for the barriers of supply chain management.

\begin{tabular}{lll}
\hline No. & Subtheme & Operational definition \\
\hline II & $\begin{array}{l}\text { Infrastructure } \\
\text { Change } \\
\text { management }\end{array}$ & $\begin{array}{l}\text { This refers to the facilities required for the industry to } \\
\text { function. }\end{array}$ \\
$\begin{array}{l}\text { This refers to the approach of introducing change and } \\
\text { ensuring that everyone understands and embraces the } \\
\text { changes taking place. }\end{array}$ \\
III & $\begin{array}{l}\text { Health and } \\
\text { safety }\end{array}$ & $\begin{array}{l}\text { This entails upholding and following health and safety } \\
\text { standards based on requirements for the industry. }\end{array}$ \\
IV & $\begin{array}{l}\text { Nature of } \\
\text { industry }\end{array}$ & $\begin{array}{l}\text { This refers to the sector to which an organisation is } \\
\text { affiliated. }\end{array}$ \\
V & $\begin{array}{l}\text { SCM skills and } \\
\text { qualifications }\end{array}$ & $\begin{array}{l}\text { This refers to ensuring that candidates competent and } \\
\text { qualified in SCM are recruited into the organisation. }\end{array}$ \\
\hline
\end{tabular}

SCM, supply chain management.
'There are frustrations brought by operating times of load points versus offloading places. There is a lack of communication within the whole supply chain. The mills have more business and orders but have not upgraded their infrastructure for years.' (P4, male, Transport Director, age 60-65 years)

'There is limited infrastructure such as limited storage, loading points which then causes huge problems. Infrastructure built in the past was based solely on rail, but now that we use more road, there have been no upgrades to accommodate road as a mode of transport.' (P9, male, Logistics Manager, age $30-40$ years)

The findings emphasise that very little attention has been directed to infrastructure development. Infrastructure is a vital factor in facilitating the effective and efficient movement of goods. The animal feed industry has grown significantly in the past years, especially with the rise in imports and exports. This has had a considerable impact on the operations and performance of the supply chain. Apparently, the development of infrastructure has not supported the growth of the animal feed supply chain. For instance, the movement of containerised traffic through the ports in the Western Cape has increased, yet there has been no infrastructure development to match this growth. Also, the animal feed supply chain was traditionally centred on rail transport as the primary mode of moving raw materials. However, with theincreased loads, road transportation has become necessary, but the available infrastructure cannot cope. The natural result of this infrastructural inadequacy is that supply chain efficiency is limited, as it becomes more costly to transport both raw materials and animal feed using the current congested and strained infrastructure.

\section{Change management}

Ineffective change management has significantly impacted current and new staff in the animal feed industry. The comments by participants portray the need to integrate old and new ideas and people in the animal feed industry:

'The major barrier is that people are not working together. The people in the industry are used to the way things were done in the past. Many people are opposed to change.' (P6, female, Purchasing Manager, age 30-40 years)

One of the procurement managers referred to the current state of affairs in his firm and industry as a whole:

'There are different role players between procurement and operations teams. The lack of teamwork has been increased due to new staff members joining the organisation and bringing in new ideas and ways of doing things. This has led to a strained relationship between departments and firms. In my firm, those receiving raw materials do not want to work as a team with new members in procurement.' ( $\mathrm{P} 8$, female, Procurement Manager, age $40-50$ years)

The supply chain executive, on the other hand, indicated how top management always tries to assist staff in adapting to change:

'Change is and will always be a huge barrier in the supply chain. From a strategic view, I believe we are trying to ensure this is filtered down the organisation. However, this is not easy. As we 
get to the lower level of the organisation, there is little willingness to change and do things differently. The perspective is "why should we change what's not broken".' (P5, male, Supply Chain Executive, age 50-60 years)

The remarks by participants suggest that resistance to change and ineffective change management are primary are constraints to the implementation of SCM in the animal feed industry. Change management is the process whereby an organisation manages its transition and transforms its strategy (Rousseau 2020). Through change management, an organisation can create and introduce new plans that entail how the change will be effected and controlled and how all employees will be assisted to adapt to it (Rousseau 2020). Unfortunately, the failure or lack of proper change management has affected the flow of operations. Introduction of new procedures and policies has not been taken lightly by employees who have been in the industry for many years. New staff are considered as a threat, and there is a fixation with the old approaches to working, making it difficult for new members to become a part of current teams. Resistance to change is also directed at the introduction of new technology, the growth of firms and the integration of new acquisitions. It is crucial then that the efforts by top management be strengthened on the operational level, where resistance to change is more pronounced.

\section{Health and safety}

Health and safety seemed to be another barrier to SCM in the animal feed industry. The most dominant issue emerging pertained to biosecurity, which are measures and procedures intended to protect the population against harmful biochemical or biological substances (Food and Agriculture Organization 2007). The problem emanated from the outbreak of AI in South Africa in 2016. The statement below by the supply chain executive provides a background to the situation:

'Biosecurity at mills is a huge factor. There was an outbreak of AI which impacted the animal feed industry immensely. After this, there has been resistance to implement certain procedures because of AI.' (P5, male, Supply Chain Executive, age $50-60$ years)

South African law dictates that health and safety regulations such as the National Environmental Management: Biodiversity Act (Republic of South Africa, NEMBA, 2004) and the Occupational Health and Safety Act (No. 85 of 1993) should be followed at all workplaces. The outbreak of AI in 2016 placed the animal feed industry on high alert and compelled different firms to collaborate and put in place measures to prevent the spread of the disease onto their premises. This was accomplished by adhering to the AFMA transportation protocols across all feed mills, ensuring that there was minimal traffic of biological organisms through the supply chain. For instance, any trucks that offloaded at a farm that had AI could only be allowed back in the mill to load after $24 \mathrm{~h}$, and also after going through the biosafety checks, despite the delays involved. The industry has, however, remained in this vigilance mode several years after the outbreak was contained and addressed. Delays and additional costs associated with such procedures are all assumed by the animal feed producers.

\section{Nature of the industry}

Nature of the industry refers to the sector to which an organisation is affiliated. Participants indicated that because of the nature of the animal feed industry, SCM is not viewed as a strategic activity. It is instead considered as an auxiliary function that provides support to the central core of the animal feed business. The following observation by one of the participants reflects this situation:

'Structure of the business such as the SCM is seen as a service department and not directly linked to the feed mills apart from providing services.' (P5, male, Supply Chain Executive, age 50-60 years)

One of the procurement managers echoed similar thoughts and highlighted the shortcomings and inadequacy of the integration of the SCM by his firm:

'The nature of the business and how there are various pillars in the whole firm. How the supply chain function is set up is a barrier to its implementation. There is no proper structure for the departments.' (P2, male, Procurement Manager, age 45-50 years)

The animal feed industry is mainly focused on providing food to livestock. In this way, its principal business is the distribution of feed directly to the farms or retailers. Unfortunately, in some of the firms, SCM is peripheral because the emphasis is on adding value by keeping the livestock nourished. The reality is that SCM is central to the entire process when the impact of procurement and logistics and its other activities is considered. Perhaps, it is the lack of knowledge and skill about SCM and its strategic role that has led to this situation. This makes SCM education an intervention that requires attention in the animal feed industry.

\section{Supply chain management skills and qualifications}

Participants commonly shared the view that the employment of staff who are skilled and knowledgeable in SCM was a major barrier to the animal feed industry as a whole. However, participants, whilst acknowledging that people with such skills and qualifications were scarce, also acknowledged the positive strides that had been made in addressing this challenge within the industry. For instance, the supply chain executive appreciated the role of skills and qualifications in the animal feed supply chain and noted how this has applied to his firm. This is captured in the following excerpt:

'Executive management's commitment to compliance ensures a smooth flow of the supply chain. HR ensures smooth implementation by having the right people in the right positions for which they are qualified. Implementation is now easy due to this. In logistics, it's better to have one knowledgeable person responsible for one thing instead of having many people.' (P5, male, Supply Chain Executive, age 50-60 years) 
Similar sentiments were echoed by the demand planning manager, who added:

'The appointment of new people has been great, and now there is a pool of specialised staff. This has helped to bring in new perspectives, which will see an increase in productivity and efficiency that has been missing in the supply chain.' (P1, male, Supply Chain Executive, age 25-30 years)

The shortage of skills within the SCM profession in South Africa is a widely recognised perennial problem (Heyns \& Luke 2012). Most recently, South African Manufacturing (SAManufacturing 2019) mentioned that a shortage of supply chain professionals persists and continues to be a threat to multiple supply chains, businesses and the national economy. The animal feed industry is not immune to such skills challenges. Consistently, the comments by participants portray their appreciation of the importance of skills and qualifications in the optimisation of SCM within the animal feed industry. Participants appear to be grateful that there have been efforts at addressing the gaps in this area, and this has led to some positive spinoffs for the industry. Consistent with this finding, Bak, Jordan and Midgley (2019) mention that the competency of staff, as demonstrated by their levels of both hard and soft skills and qualifications, increases efficiency and effectiveness in SCM. Possession of the right skills set and specialised employees in the supply chain industry is a source of competitive advantages in South Africa (Heyns \& Luke 2012). This illustrates that it is essential for staff in the animal feed industry to be equipped with the knowledge and skills required to perform their duties successfully, as this facilitates a more effective and efficient SCM function.

\section{Supply chain disruptions}

Three supply chain disruptions were identified in the thematic analysis of data. These are economic factors, natural disasters and customer loyalty. The operational definitions of these supply chain disruptions are provided in Table 4.

\section{Economic factors}

Economic factors emerged as a significant SCM disruption to the animal feed industry. Participants pointed to the current economic instability in South Africa and how it further impacts the feed industry. The following thought from one of the procurement managers captures this finding:

'There has been a rise in the cost of raw materials. On the other hand, fuel price is escalating, and this has a huge influence on the transportation of raw materials. Due to the lack of availability of raw materials, there is now a need to get them from different locations.' (P8, female, Procurement Manager, age 40-50 years)

TABLE 4: Operational definitions for supply chain disruptions.

\begin{tabular}{ll}
\hline No. Subtheme & Operational definition \\
\hline I Economic factors & $\begin{array}{l}\text { These are the drastic changes in the economy that are usually } \\
\text { unexpected. }\end{array}$ \\
II $\begin{array}{l}\text { Natural disasters } \\
\text { and diseases }\end{array}$ & $\begin{array}{l}\text { This refers to the natural acts of the earth which occur } \\
\text { naturally but have a considerable effect on the geography and } \\
\text { the occurrence of diseases in the geographical area. }\end{array}$ \\
III Customer loyalty & \begin{tabular}{l} 
The ability of a firm to retain its customers over a long period. \\
\hline
\end{tabular}
\end{tabular}

The finance manager further lamented the impact of adverse economic developments:

'There have been many policy changes in parliament. The country's relationship with the USA has affected the African Growth and Opportunity Act (AGOA) agreement is under threat. Recently there have been trading wars between USA and Turkey and China, which has been affecting South Africa as a whole.' (P7, female, Finance Manager, age 40-50 years)

The animal feed industry is cost-driven. The ability to acquire cheaper raw materials leads to the ability to sell the final feed at lower prices. This has been hindered by the numerous economic factors that contribute to the manufacturing of the feed. As indicated by the participants, economic turbulence has been disruptive. An increase in interest rates, government policies and taxes play a significant role in the final price of the feed. The loss of value of the rand against major currencies, the constant fuel price increases in South Africa and the loss of investor confidence in the country have increased the cost of producing animal feed. Thus, the stronger the national economy, the easier it is for the animal feed industry to operate successfully.

\section{Natural disasters and diseases}

The consensus from participants was that natural disasters and disease had affected the animal feed supply chain. The extracts below reflect this narrative:

'The drought experienced in the Western Cape in the past years had a huge impact on the supply of raw materials to the feeds industry.' ( $\mathrm{P} 1$, male, Demand Planning Manager, age 25-30 years)

'The outbreak of bird flu had a huge impact on the industry. We lost much business.' (P9, male, Logistics Manager, age 30-40 years)

A natural disaster is an event that is caused by the natural forces of the earth where considerable damage and, sometimes, loss of life occurs (Bankoff, Frerks \& Hilhorst 2003). Natural disasters vary and can be in the form of, although not limited to, drought, earthquakes, tsunamis and flooding. A drought is a period when there is inadequate water for prolonged periods (Wolchover 2018). As mentioned by participants, frequent droughts in South Africa have impaired the animal feed industry. Similarly, there have been disease outbreaks, such as AI in 2016 and the foot and mouth disease in 2018. Such occurrences effectively reduced the national herd of livestock, with a negative impact on the quantities of animal feed required. Reduced quantities of animal feed, in turn, lowered the revenue and income of firms in this industry.

\section{Customer loyalty}

Participants indicated that there is low customer loyalty in the animal feed industry. Customers are willing to switch to alternative suppliers, even for minor reasons. The following remarks by a demand planning manager support this view:

'The customers are always switching companies looking for cheap products. There is a rise in volumes lost to competitors. Customers fluctuate, they are dependent on prices and not loyalty.' (P1, male, Demand Planning Manager, age 25-30 years) 
One supply chain executive further added to these sentiments:

'There is overcapacity in the feed mill industry. This leads to all the competitors fighting for the same customers. There is never a guarantee that the customer will stay with us. They always go where there is cheaper feed at that time.' (P5, male, Supply Chain Executive, age 50-60 years)

Customer loyalty relates to customers' intention to remain committed to a specific provider in the marketplace by repeating their purchasing experiences (Thakur 2016). In most cases, customers do not consider the cost implications only, but the relationship and loyalty they have built with their supplier as well. This is not the case in the animal feed industry, where the decision to buy is not based on past relationships (although it might play a role in the final decision). Instead, the determining factor is cost, whereby farmers prefer to purchase from the cheapest of the suppliers at that time. This makes the lack of customer loyalty a significant disruption on the supply chain of each animal feed producer. Business is not guaranteed, but the feed mills have to operate on a month-to-month basis as they supply to farmers. Exacerbating the situation is oversubscription within this industry, as there seem to be too many animal feed manufacturers, leading to overcapacity or an oversupply of the product.

\section{Conclusion}

This research aimed to investigate the SCM-related factors for growth (enablers), barriers and disruptions within the animal industry in the Western Cape Province of South Africa. The themes extracted from this study pointed to a variety of enablers, barriers and disruptions of SCM in the animal feed industry. The study identified three supply chain enablers which are technology, bargaining power of the industry and unity, and the implementation of procurement and supply chain strategies. The barriers identified included the lack of infrastructure, lack of change management, health and safety restrictions, structure of the industry and skills and qualifications. These barriers are the forces that negatively impact the implementation and success of SCM. The disruptions brought to light included the harsh and volatile economic conditions currently prevailing in South Africa, the prevalence of natural disasters and outbreaks of diseases, and the lack of customer loyalty. These factors also work as forces against the successful implementation of SCM. This study, therefore, confirms that regardless of the volatility of the industry and the market, SCM strategy is an important strategic activity within the animal feed supply chain.

\section{Theoretical and managerial implications}

This study contributes to scientific knowledge as it generates information about the dynamics regarding theimplementation of SCM, which may lead to a better understanding of operations in the animal feed industry. Because there is a lack of empirical research in this area, this study represents a pioneering attempt at investigating the SCM enablers, barriers and disruptions in the animal feed industry. Thus, this study provides a foundation on which further local research can be conducted for the improvement of SCM in the animal feed industry.

Practically, this study provides information regarding the factors (enablers) that deserve the attention of SCM managers and practitioners who intend to improve the performance of the animal feed supply chain. By providing information on SCM barriers and disruptions, risk management initiatives in the animal feed industry can be developed. As the animal feed industry has no control over the upgrading of national infrastructures such as roads and ports, both mills and storage facilities should be located closer to suppliers and customers or ports of entry to use location as a source of competitive advantage. Training focusing on change management is necessary from top management to lowerlevel staff to ensure that change is embraced as part of business strategies. Such training should include the use of relevant change management models that can guarantee success if applied in the industry. SCM education and training is also necessary to ensure that all managers and staff understand the importance of adopting and integrating SCM as a core strategy in firms. Given the unpredictable nature of the climate and pandemics, disaster response strategies should be put in place in case of the occurrence of any catastrophe and or disease outbreaks. The loyalty of farmers can be boosted by providing value-added benefits to customers that purchase feed from the mills. These added benefits may include providing some incentives such as inputs and discounts to loyal customers. Also, the oversupply of animal feed in the country could be addressed by boosting exports to other markets elsewhere across the world. More aggressive global marketing strategies should, therefore, be adopted to ensure that a viable output avenue is created for locally produced animal feed.

\section{Limitations and suggestions for future research}

This study is limited in its use of a qualitative approach, which suggests that the findings are subjective opinions of the participants. Additionally, the study is limited as it was based on a small sample of $n=9$ participants, which limits the transferability of its findings to other animal feed industries elsewhere in South Africa and beyond. The applicability of the study to other contexts is further obstructed by the use of participants that were based in one province only (Western Cape).

Several suggestions for future research have been identified. This study can also be extended to animal feed industries in other provinces of South Africa, which provides a basis for scientific comparisons. Similar studies can be conducted in different industries and sectors that are critical to the South African economy, such as mining, steel, automotive, 
petrochemicals and electronics, amongst others. The findings from such studies can be useful in accelerating and improving the implementation of SCM in these industries. A mixed-method approach could also be applied to elicit further information that could not be covered in this study. Further research can also consider biosecurity issues resulting from animal-based protein components. An example includes the European experience where dairy products such as intervention milk powder and butter are now being added to animal feeds. Such issues have become prominent and deserve future attention to discover whether such procedures can benefit the animal feed industry in South Africa. Other possible topics for the future include how the health and safety of operators can be improved and how challenges related to the importation of raw materials and exportation of animal feed manufactured in South Africa can be overcome.

\section{Acknowledgements}

The authors would like to thank the various participants for their support and commitment to this study.

\section{Competing interests}

The authors have declared that no competing interests exist.

\section{Author's contributions}

P.M.G. collected the data and performed the review of article. C.M. wrote the research methodology and results section of the article.

\section{Ethical consideration}

Ethical clearance was obtained from the University of South Africa's School of Business Leadership Research Ethics Review Committee (GSBL CREC) (Reference number: 2018 SBL_MBL_036_FA).

\section{Funding information}

This research received no specific grant from any funding agency in the public, commercial or not-for-profit sectors.

\section{Data availability statement}

Qualitative data collected in this study are available upon request.

\section{Disclaimer}

The views and opinions expressed in this article are those of the authors and do not necessarily reflect the official policy or position of any affiliated agency of the authors.

\section{References}

Agriculture News South Africa, 2018, 'SA feed industry experiences $0.7 \%$ sales drop for 2017/18', Bizcommunity, viewed 09 March 2020, from https://www. bizcommunity.com/Article/196/358/180010.html.
Animal Feed Manufacturers' Association, 2019, AFMA industry statistics, viewed 30 March 2020, from https://www.afma.co.za/industry-statistics/.

Auramo, J., Kauremaa, J. \& Tanskanen, K., 2005, 'Benefits of IT in supply chain management: An explorative study of progressive companies', International Journal of Physical Distribution \& Logistics Management 35(2), 82-100. https:// doi.org/10.1108/09600030510590282

Bak, O., Jordan, C. \& Midgley, J., 2019, 'The adoption of soft skills in supply chain and understanding their current role in supply chain management skills agenda: A UK perspective', Benchmarking: An International Journal 26(3), 1063-1079. https:// doi.org/10.1108/BIJ-05-2018-0118

Bankoff, G., Frerks, G. \& Hilhorst, D., 2003, Mapping vulnerability: Disasters, development and people, Earthscan, London.

Baker, S.E. \& Edwards, R., 2012, How many qualitative interviews is enough?, National Center for Research Methods, viewed 29 April 2020, from http://eprints.ncrm. ac.uk/2273/.

BizVibe, 2018, Industry outlook: Animal feed industry in South Africa, viewed 30 March 2020, from https://www.bizvibe.com/blog/agriculture/animal-feedindustry-in-south-africa-2018/.

Blumberg, B.F, Cooper D.R. \& Schindler P.S., 2014, Business research methods, 4th edn., McGraw Hill Education, Boston, MA.

Bolton, T., 2015, 'The state of the South African poultry industry. Supermarket and retailer', viewed 09 April 2020, from https://www.supermarket.co.za/flipbooks/ supermarket_retailer/March\%202015/S\&R\%202015-3\%20March\%20flipbook.pdf.

Braun, V. \& Clarke V., 2006, 'Using thematic analysis in psychology', Qualitative ResearchinPsychology3(2),77-101.https://doi.org/10.1191/1478088706qp063oa

Charmaz, K., 1990, 'Discovering chronic illness: Using grounded theory', Social Science and Medicine 30(11), 1161-1172. https://doi.org/10.1016/0277-9536(90)90256-R

Chartered Institute of Procurement and Supply (CIPS), 2016, The top 10 causes of supply chain disruption loss, viewed 31 March 2020, from https://www.cips.org/ supply chain disruption loss, viewed disruption-loss/.

Clutton-Brock, J., 1999, A natural history of domesticated mammals, Cambridge University Press, Cambridge.

Corbin, J. \& Strauss, A., 2008, Basics of qualitative research: Techniques and procedures for developing grounded theory, 3rd edn., Sage, Thousand Oaks, CA. https://doi.org/10.4135/9781452230153

Cresswell, J.W. \& Plano Clark, V.L., 2011, Designing and conducting mixed method research, 2 nd edn., Sage, Thousand Oaks, CA.

Department of Agriculture, Forestry and Fisheries (DAFF), 2018, South African feed market analysis report, viewed 20 March 2020, from https://www.nda.agric.za/ doaDev/sideMenu/Marketing/Annual\%20Publications/Commodity \%20Profiles/ field $\% 20$ crops/South $\% 20$ African $\% 20$ Animal $\% 20$ Feeds $\% 20$ Market $\% 20$ Analysi\%20Report\%202018.pdf.

Department of Agriculture, Forestry and Fisheries (DAFF), 2020, Animal production, viewed 31 March 2020, from https://www.daff.gov.za/daffweb3/Branches/ Agricultural-Production-Health-Food-Safety/Animal-Production/LivestockProduction.

Department of Environmental Affairs, 2017, Full technical report on the implications of climate change for the agriculture sector in South Africa, viewed 31 March 2020, from https://www.environment.gov.za/sites/default/files/docs/implications climatechange_foragriculture.pdf.

Digital Agriculture and Farming Handbook, 2020, Animal husbandry, viewed 30 March 2020, from https://agribook.co.za/livestock/animal-husbandry/.

Dunn, L., 2017, 'Local broiler feed industry - Threats and opportunities - Last but not least', AFMA Matrix 26(2), 48-48.

Dworkin, S.L., 2012, 'Sample size policy for qualitative studies using in-depth interviews', Archives of Sexual Behavior 41, 1319-1320. https://doi.org/10.1007/ s10508-012-0016-6

Du Toit, D. \& Vlok, P.J., 2014, 'Supply chain management: A framework of understanding', South African Journal of Industrial Engineering 25(3), 25-38. https://doi.org/10.7166/25-3-743

Evans, J., 2019, 'SA's foot and mouth disease-free status temporarily suspended following outbreak', News24, viewed 30 March 2020, from https://www.news24. com/SouthAfrica/News/sas-foot-and-mouth-disease-free-status-temporarilysuspended-following-outbreak-20190108.

Fawcett, S.E, Ellram L.M. \& Ogden J.A., 2014, Supply chain management: From vision to implementation, 1st edn., Pearson New International Edition, Harlow, Essex.

Food and Agriculture Organization, 2007, FAO Biosecurity Toolkit, viewed 09 April 2020, from http://www.fao.org/3/a1140e/a1140e00.htm.

Gonera, P., 2018,'Supply chain enablers and disruptions in the animal feed industry in the Western Cape Province', unpublished Master's dissertation, Graduate Schoo of Business Leadership, Department of Supply Chain Management, University of South Africa, South Africa.

Heyns, G. \& Luke, R., 2012, 'Skills requirements in the supply chain industry in South Africa', Journal of Transport and Supply Chain Management 6(1), a34. https://doi. org/10.4102/jtscm.v6i1.34

Jahari, C., Kilama, B., Dube, S. \& Paremoer, T., 2018, Growth and development of the oilseedsedible-oils value chain in Tanzania and South Africa, CCRED Working Paper, 3 , viewed 09 edible-oils value chain in Tanzania and South Africa, CCRED Working Paper, 3, viewed 09 April 2020, from https://static1.squarespace.com/static/52246331e4b0a46e5f1b8ce5/ t/5a8acb119140b7effc1ef7fa/1519045406594/AIDIRP_D
value+chain+in+TZ+and+SA+Research+Report.docx.pdf.

Jamshed, S., 2014, 'Qualitative research method-interviewing and observation', Journal of Basic and Clinical Pharmacy 5(4), 87-88. https://doi.org/10.4103/09760105.141942 
Kim, Y., Chen, Y.S. \& Linderman, K., 2015, 'Supply network disruption and resilience: A network structural perspective', Journal of Operations Management 33(1), 43-59. https://doi.org/10.1016/j.jom.2014.10.006

Korstjens, I. \& Moser, A., 2018, 'Series: Practical guidance to qualitative research. Part 4: Trustworthiness and publishing', European Journal of General Practice 24(1) 120-124. https://doi.org/10.1080/13814788.2017.1375092

Le Bars, J. \& Le Bars, P., 1999, 'Storage of compound feeds for animals: Shelf-life and real-time detection of fungal development', Proceedings of the 7th International Working Conference on Stored-product Protection, Volume 1, Beijing China, Sichuan Publishing House of Sichuan Publishing House of Science and Technology, Chengdu, China, 14-19 October 1998, viewed 29 April 2020, from http://spiru.cgahr.ksu.edu/proj/
iwcspp/pdf2/7/280.pdf.

Lee, N. \& Lings, I., 2008, Doing business research: A guide to theory and practice, Sage, London.

Leedy, P.D. \& Ormrod, J.E., 2015, Practical research, planning and design, 11th edn., Pearson, Boston, MA.

Lincoln, Y.S. \& Guba, E.G., 1985, Naturalistic inquiry, Sage, California, CA. https://doi org/10.1016/0147-1767(85)90062-8

Louw, A., Schoeman, J. \& Geyser, M., 2013, 'Pork and broiler industry supply chain study with emphasis on feed and feed-related issues', Semantic Scholar, viewed 08 April 2020, from https://www.semanticscholar.org/paper/Pork-andbroiler-industry-supply-chain-study-with-Louw-Schoeman/c0764fe70a908ff 4590eb2fe5a8e06db880309c4.

Lysons, K. \& Farrington, B., 2012, Purchasing and supply chain management, 8th edn., Pearson, New York.

Markowiak, P. \& Śliżewska, K., 2018, 'The role of probiotics, prebiotics and synbiotics in animal nutrition', Gut Pathogens 10(21), 1-20. https://doi.org/10.1186/ s13099-018-0250-0

Maré, F., 2017, 'The local animal feed industry: Growing figures - Agribusiness update', FarmBiz 3(3), 29-31.

Mason, M., 2010, 'Sample size and saturation in PhD studies using qualitative interviews', Forum: Qualitative Social Research 11(3), 1-19.

McTavish, E.J., Decker, J.E., Schabel, R.D., Taylor, J.F. \& Hillis, D.M., 2013, 'New world cattle show ancestry from multiple independent domestication events', Proceedings of the National Academy of Sciences of the United States of America 110(15), 1398-1406. https://doi.org/10.1073/pnas.1303367110

Meissner, H.H. \& Scholtz, M. \& Palmer, A., 2013, 'Sustainability of the South African Livestock Sector towards 2050 Part 1: Worth and impact of the sector', South African Journal of Animal Science 43(3). https://doi.org/10.4314/sajas. v43i3.5

Morse, J.M., 2000, 'Determining sample size', Qualitative Health Research 10(1), 3-5. https://doi.org/10.1177/104973200129118183

Ncube, P., Roberts, S. \& Zengeni, T., 2016, Development of the animal feed to poultry value chain across Botswana, South Africa, and Zimbabwe, CCRED Working Paper No. 2016/9, viewed 08 April 2020, from https://papers.ssrn.com/sol3/ papers.cfm?abstract_id=2923097. https://doi.org/10.35188/UNU-WIDER/2016/ pap-4.
Ncube, P., Roberts, S., Zengeni, T. \& Samboko, P.C., 2017, Identifying growth opportunities in the Southern African Development Community through regiona value chains, WIDER Working Paper No. 2017/4, viewed 08 April 2020, from https://pdfs.semanticscholar.org/dfce/63b981b719db8a1e6622ff746862 bdec2 6a4.pdf?_ga=2.27723324.1228428936.1586344141-392072154.1553376816.

Nowell, L., Norris, J., White, D. \& Moules, N., 2017, 'Thematic analysis: Striving to meet the trustworthiness criteria', International Journal of Qualitative Methods 16(1), 1-13. https://doi.org/10.1177/1609406917733847

Republic of South Africa, 2004, National Environmental Management: Biodiversity Act (NEMBA), Government Printers, Pretoria.

Rousseau, D.M., 2020, 'Making evidence-based organizational decisions', Organizational Dynamics 49(1), 100756. https://doi.org/10.1016/j.orgdyn.2020.100756

Rust, J.M. \& Rust, T., 2012, 'Climate change and livestock production: A review with emphasis on Africa', South African Journal of Animal Science 43(3), 256-267. https://doi.org/10.4314/sajas.v43i3.3

SAManufacturing, 2019, Fighting the supply chain skills crisis, viewed 10 May 2020 from https://www.samanufacturing.co.za/fighting-the-supply-chain-skills-crisis/.

South African Reserve Bank, 2020, Selected historical rates, viewed 30 March 2020, from https://www.resbank.co.za/Research/Rates/Pages/SelectedHistoricalExchange AndInterestRates.aspx.

Sridharan, U.M, Caines W.R. \& Patterson C.C., 2005, Implementation of supply chain management and its impact on the value of firms, Supply Chain Management: An International Journal 10(4), 313-318. https://doi.org/10.1108/1359854051 0612785

Stone, S. \& Masondo, S., 2020, "If not IMF, then give me the money" - Mbowen after lockdown, junk status batters SA', City Press, viewed 30 March 2020, from https://city-press.news24.com/News/no-time-for-ideology-if-not-imfthen-give-me-the-money-mboweni-after-lockdown-junk-status-batterssa-20200329.

Thakur, R., 2016, 'Understanding customer engagement and loyalty: A case of mobile devices for shopping', Journal of Retailing and Consumer Services 32, 151-163. https://doi.org/10.1016/j.jretconser.2016.06.004

The Organic Farmer, 2020, Sunflower is a good source of animal feed, viewed 30 March 2020 from http://www.theorganicfarmer.org/Articles/sunflower-goodsource-animal-feed.

Watson, A., 2019, 'Foot-and-mouth disease outbreak puts SA livestock at risk', The Citizen, viewed 30 March 2020, from https://citizen.co.za/news/south-africa/ general/2059781/foot-and-mouth-disease-outbreak-puts-sa-livestock-at-risk/.

Wolchover, N., 2018, 'What is a drought?', LiveScience, viewed 09 April 2020, from https://www.livescience.com/21469-drought-definition.html.

Van der Merwe, E., Nwokolo, M., Hartely, R. \& Mills, G., 2020, 'How much could coronavirus cost the SA economy? A preliminary estimate', Daily Maverick, viewed 30 March 2020, from https://www.dailymaverick.co.za/article/2020-0327-how-much-could-coronavirus-cost-the-sa-economy-a-preliminary-estimate/.

Van Ryssen, J.B.J., 2014, Aspects of livestock production in South Africa, College of Agricultural Sciences, Oregon State University, viewed 31 March 2020, from https://web.archive.org/web/20140517121527/http://oregonstate.edu/dept/ eoarc/sites/default/files/publication/312d.pdf. 